\title{
Pembelajaran Berbasis Teori Van Hiele Terhadap Pemahaman Bangun Geometri Tunanetra
}

\author{
Rusdiana Indriani, Umi Safiul Ummah, Sihkabuden \\ Universitas Negeri Malang \\ E-mail: rusdianaindriani07@gmail.com
}

\begin{abstract}
Abstrak: Tunanetra merupakan anak yang memiliki hambatan pada indera penglihatan. Tunanetra dibagi menjadi dua yaitu buta yang dalam pembelajarannya diajarkan Braille, sedangkan kurang lihat (low vision) dalam pembelajarannya perlu modifikasi khusus karena penglihatan sentral yang dimiliki antara 20/200 feet atau 20/70. Anak tunanetra mendapatkan informasi dari lisan dan taktil, karena hambatan yang dimiliki tersebut berpengaruh pada pemahaman persepsi dan mengenal bangun. Teori Van Hiele adalah teori yang mampu melatih mengembangkan pemahaman siswa dengan beberapa langkah berdaskan tingkatannya. Tujuan dari Penelitian ini adalah (1) Untuk mengetahui kemampuan dari siswa tunanetra SDLB Kedungkandang Malang dalam memahami bangun datar geometri sebelum menggunakan teori Van Hiele. (2) Untuk mengethui kemampuan siswa tunanetra di SDLB Kedungkandang Malang dalam memahami bangun datar geometri sesudah menggunakan teori Van Hiele. (3) Untuk mengtahui adanya perbedaan kemampuan memahami bangun datar geometri sebelum maupun sesudah menggunakan teori Van Hiele pada siswa tunanetra kelas V di SDLB Negeri Kedungkandang Malang. Hasil penelitian menunjukkan rata-rata yang diperoleh pada pre-test sebesar 49,8 dan nilai rata-rata yang diperoleh seteah diberikan perlakuan (treatment) meningkat meningkat sebesar 68.1. Berdasarkan hasil penelitian, dapat disimpul bahwa adanya pengaruh penggunaan metode Van Hiele terhadap kemampuan mengenal geometri bangun datar.
\end{abstract}

Kata Kunci: Van Hiele, Pemahaman Geometri Bangun Datar, Tunanetra

\begin{abstract}
Abstrac: Blind people are children who have bdifficulties to the sense of sight. Blind are divided into two, the total blindness in which learning is taught by Braille, while the less vision (low vision) in learning needs special modification because of the central vision held between 20/200 feet or 20/70. Blind children get information from oral and tactile, because the barriers that have an effect on understanding perception and knowing two-dimentional figure. Van Hiele method is able to train students to develop understanding with several steps based on level. The purpose of this study are (1) To know the blind student's ability SDLB Kedungkandang Malang in understanding the geometry of two-dimentional figure thinking before using Van Hiele theory. (2) To know the ability of blind students in SDLB Kedungkandang Malang to understand the two-dimentional figure geometry after using Van Hiele theory. (3) To know the difference of ability to understand the two-dimentional figure geometry before and after using Van Hiele theory on students with visual impairment grade V in SDLB Negeri Kedungkandang Malang. The results showed the average obtained on pre-test of 49.8 and the average value obtained after treatment was increased increased by 68.1 . Based on the result of the research, it can be concluded that the ieffect of Van Hiele method to the ability of recognize the geometry of two-dimentional figure.
\end{abstract}

Key Word: Blind childern, Geometry of two-dimentional figure thinking, Van Hiele

Matematika merupakan ilmu pengetahuan paling dasar yang sangat diperlukan baik kehidupan sehari-hari maupun untuk kemajuan sains dan tekonologi sehingga matematika perlu dibeklkan kepada siswa peserta didik sejak SD. Matematika dapat meningkatkan kemmpuan berpikir logis, sistematis, logis, kritis dan kreatif, serta kemampuan kerjasama. Matematika merupakan ilmu yang tidak hanya berhubungan dengan bilangan-bilangan serta operasi-operasinya, melainkan juga unsur ruang sebagai sasaranya Hudojo (2005:35). Dari penjelasan seperti itu belum memenuhi sasaran matematika yang lain, yaitu ditunjukkan pada hubungan, pola, bentuk, dan struktur. Sehingga matematika kerap kali dipandang sebagai pelajaran yang menakutkan dan sulit, sehingaa bisa menjadi faktor yang mempengaruhi pemikiran siswa untuk enggan mempelajari matematika terutama pada tingkat SD. Pada matematika terdapat cabang yang mempelajari mengenai bangun ruang yaitu geometri.

Matematika mengenai bangun, bentuk, dan ukuran benda-benda, dan telaah sifat-sifat tetap dari elemenelemen yang diketahui, dibawah pengaruh grup-grup tranformasi khusus, yang disebut dengan geometri yang merupakan cabang dari matematika Aviana, (2012). Salah satu tujuan dari geometri menurut Walle (2006:150), visulalisasi mencakup pengenalan bentuk-bentuk di lingkungan sekitar, pembangunan hubungan antara benda-benda dua dimensi dengan tiga dimensi, serta kemampuan untuk menggambar dan mengenal bentuk dari berbagai sudut pandang. Menurut Smart (2010:36) tidak dapat melihat dua jari di depan muka atau hanya melihat sinar cahaya saja, mereka memerlukan pemebelajaran orientasi mobilitas dan menggunakan huruf Braille. Sedangkan low vision 
merupakan mereka yang dapat melihat sesuatu namun perlu didekatkan atau dijauhkan dari objek yang akan dilihat. Ada beberapa penyandang low vision juga memiliki pandangan yang kabut untuk melihat objek sehingga mereka perlu menggunakan alat bantu berupa kacamata atau kontak lensa. pendapat lain mengenai pengertian tunanetra yaitu terjadinya kerusakan pada kornea mata yang meliputi kornea kering, keriput lensa mata menjadi keruh atau saraf yang menhubungkan mata dengan otak mengalami gangguan (Efendi, 2006:30). Beberapa ahli melakukan penelitian serta dilakukan perbandingan langsung antara anak tunanetra dengan anak awas secara langsung, hasilnya masih dipertanyakan karena kedua kelompok tersebut di tes dalam kondisi yang berbeda. Sebagai contoh, untuk membaca huruf Braille atau meraba macam-macam bentuk dari sebagian tes prestasi belajar, prosesnya lebih lambat dibandingkan dengan anak awas yang membaca huruf latin atau huruf untuk orang awas. Hal tersebut terjadi karena anak tunanetra memerlukan waktu untuk mengidentifikasi serta berpikir huruf apa yang mereka raba serta menggabungkan setiap huruf tersebut menjadi kata atau kalimat berbeda dengan anak tanpa hambatan penglihatan mereka bisa langsung melihat huruf-huruf yang tersusun yang membuat kata atau kalimat (Wardhani:2009).

Prestasi yang diperoleh anak penyandang tunanetra tidak memiliki perbedaan yang jauh dengan anak awas. Karena anak tunanetra masih bisa mengumpulkan informasi dari indera yang masih ada yaitu telinga dan perabaan (taktual). Anak-anak yang memiliki hambatan dalam penglihatan memiliki kebutuhan yang harus dialaminya sendiri secara konkret dan melakukan apa yang dia pelajarai untuk membantunya membuat persepsi sendiri (learning by doing). Mereka dapat melakukan kedua hal diatas dengan mengorientasikan pengalaman belajar dengan mengalami kejadian nyata dan menggunakan benda atau material yang khsusus seperti menyediakan bermacam-macam pengalaman mengenal bentuk, ukuran, dan teksturHildayani, (2014:8.10). Sehingga perlu adanya strategi yang mampu mengembangkan proses berpikir siswa tunanetra secara bertahap.

Pembelajaran yang dapat diterapkan pada siswa adalah pembelajaran berbasis Van Hiele. Pembelajaran berbasis Van Hiele Model pembelajaran geometri berbasis teori Van Hiele bertujuan untuk meningkatkan tingkat berpikir siswa dalam geometri (Nuraini, 2010).

Sintak dari teori Van Hiele adalah pada level pertama (visualisasi) siswa mengenali bangun-bangun datar berdasarkan bentuknya dan membedakan bangun segi banyak dan bukan segi banyak. Pada level kedua (Analisis) siswa mengenal sifat-sifat dari masingmasing bangun datar. Pada level ketiga (Abstraksi) siswa mempersepsi suatu hubungan diantara sifat-sifat , yang mana mereka menghubungkan sifat tersebut pada bentuk permukaan suatubenda.

\section{METODE}

Jenis penelitian yang dilakukan merupakan penilitian semu (Quasi Experiment). Karena pada penelitian ini perlakuan yang diberikan pada subjek tidak sepenuhnya dikendalikan. Penelitian ini menggunakan Quasi Eksperiment yang berbentuk time series design. Pada penelitian ini populasi yang diambil tidak dapat dipilih secara acak. Desain penelitian ini menggunakan satu kelompok dan tidak mengunakan kelompok kontrol. Sebelum di berikan perlakuan atau treatment, siswa diberikan pretest sebanyak empat kali. Hasil Pretest yang baik adalah $\mathrm{O}_{1}=\mathrm{O}_{2}=\mathrm{O}_{3}=\mathrm{O}_{4}$ dan perlakuan yang baik adalah $\mathrm{O}_{5}=\mathrm{O}_{6}=\mathrm{O}_{7}=\mathrm{O}_{8}$ (Sugiyono, 2015). Subjek yang digunakan pada penelitian ini sebanyak 7 siswa meliputi 2 siswa low vison dan 5 siswa tunanetra total. Yang setiap siswanya memiliki karakteristik yang berbeda.

Instrumen penelitian yang diginakan oleh peneliti yaitu berupa instrument pembelajaran, materi dan butir soal. Yang mana dapat diuji validitas nya dengan berlandaskan pada kriteria presentase validitas suatu instrument dari (Arikunto:2012). Teknik yang diguanakan dalam pengumpulan data pada penelitian ini berupa test tulis. Pretest dialakukan sebelum diberikan perlakuan (treatment) dan posttest dilakukan setelah diberikan perlakuan (treatment). Pretest dilakukan sesuai dengan instrument yang telah dibuat Untuk mengetahui kejelasan serta kestabilan kelompok sebelum diberikan perlakuan, maka peneliti melakukan pretest sebanyak empat kali. Sedangkan untuk posttest dilakukan untuk mengetahui serta mengevaluasi pengaruh penggunaan pembelajaran berbasis Van Hiele terhadap pemahaman geometri teruatama bangun datar pada siswa.

\section{HASIL DAN PEMBAHASAN}

\section{Hasil}

Data kemampuan awal diperoleh dari hasil tes kemampuan awal (pretest). Pretest dilakukan sebanyak empat kali dan dilaksanakan selama empat hari. Kegiatan pretest dilakukan untk mengetahui kemampuan awal siswa sebelum diberi perlakuan (treatment) dalam pemahaman geometri. Sebelum pelaksanaan prettest siswa diberi penjelasan secara singkat tentang beberapa bangun geometri (bangun datar) dan sifatnya. Pada kegiatan pretest ini terlihat banyak jawaban siswa yang salah. Dalam menyebutkan sifat bangun geometri, siswa masih belum mampu menjawab dengan benar. Kemudian dalam menjelaskan tentang perbedaan bangun geometri seperti persegi dan persegi panjang siswa masih belum mampu menjelaskan dengan tepat. Berikut ini adalah hasil dari kegiatan pretest: 
Tabel 1. Nilai hasil tes kemampuan awal memahami bangun geometri pada siswa tunanetra kelas V SDLB Negeri Kedungkandang Malang

\begin{tabular}{llll}
\hline No & NAMA & Nilai Akhir & Rata-rata \\
\hline 1. & $\mathrm{Ds}$ & 55 & \\
2. & $\mathrm{Ob}$ & 39.5 & \\
3. & $\mathrm{Ah}$ & 45.2 & 49.8 \\
4. & $\mathrm{Pu}$ & 49.7 & \\
5. & $\mathrm{Se}$ & 47 & \\
6. & $\mathrm{Rz}$ & 54.7 & \\
7. & $\mathrm{Az}$ & 54.5 & \\
\hline & & 348.6 & \\
\hline
\end{tabular}

Tabel 2. Nilai Siswa Setelah Diberikan Teori Van Hiele

\begin{tabular}{llll}
\hline No & NAMA & Nilai Akhir & Rata-rata \\
\hline 1. & Ds & 80.5 & \\
2. & $\mathrm{Ob}$ & 55.7 & \\
3. & $\mathrm{Ah}$ & 55.2 & \\
4. & $\mathrm{Pu}$ & 66.7 & 68.1 \\
5. & $\mathrm{Se}$ & 68.5 & \\
6. & $\mathrm{Rz}$ & 69.7 & \\
7. & $\mathrm{Az}$ & 81.5 & \\
\hline
\end{tabular}

Tabel 3. Hasil Rekapitulasi Nilai Pre-test dan Posttest

\begin{tabular}{lllll}
\hline No & NAMA & $\begin{array}{l}\text { Ni a i } \\
\text { Pretest }\end{array}$ & $\begin{array}{l}\text { Nosttest } \\
\text { Po i }\end{array}$ & $\begin{array}{l}\text { Perubahan } \\
\text { Tanda }\end{array}$ \\
\hline 1. & $\mathrm{Ds}$ & 55 & 80.5 & + \\
2. & $\mathrm{Ob}$ & 39.5 & 55.7 & + \\
3. & $\mathrm{Ah}$ & 45.2 & 55.2 & + \\
4. & $\mathrm{Pu}$ & 49.7 & 66.7 & + \\
5. & $\mathrm{Se}$ & 47 & 68.5 & + \\
6. & $\mathrm{Rz}$ & 54.7 & 69.7 & + \\
7. & $\mathrm{Az}$ & 54.5 & 81.5 & + \\
\hline
\end{tabular}

Berdasarkan dari data tabel diatas dapat diketahui rata-rata yang diperoleh saat pretest kemampuan awal siswa pada pemahaman geometri yaitu terdapat 1 siswa yang berada pada rentang nilai 0-39 dan terdapat 6 siswa yang berada pada rentang nilai 40-55. Nilai ratarata pretest yang diperoleh siswa adalah 49.8 sehingga kesimpulan yang didapatkan adalah kemampuan siswa dalam pemahaman geometri pada kegiatan pretest termasuk dalam kategori kurang mampu. Kegaiatan posttest dilaksanakan bertujuan untuk mengetahui kemampuan siswa setelah diberi perlakuan (treatment). Terlihat adanya perbedaan pada pemahaman siswa dalam menjawab pertanyaan dengan bobot soal yang sama dengan waktu perlaksanaan pre-test. Selama proses pengerjaan post-test siswa terliat antusias dan kondusif setelah diberi perlakuan (treatment). Mereka juga tenang dalam menjawab pertanyaan. Dapat diketahui niali Post-test diatas dapat diajbarkan siswa yang memperoleh nilai pada rentang 56-65 ada 2 siswa, pada rentang 66-79 ada 3 siswa, dan pada rentang 80100 ada 2 siswa. Sehingga dapat disumpulkan bahwa kemampuan mengenal geometri (bangun datar) siswa pada kegiatan post test termasuk dalam kategori baik.

Setelah diketahui nilai pre-test dan post-test dapat dilakukan rekapitulasi nilai pre- test dan nilai post-test. Rekapitulasi ini bertujuan untuk mengetahui perbandingan tingkatan kemampuan siswa dalam materi gemoetri mengenal bangun datar, sebelm dilakukan perlakuan (treatment) dan sesudah dilakukan perlakuan (treatment). Sehingga dapat diketahui apakah ada pengaruh atau tidak pembelajaran berbasis teori Van Hiele pada siswa tunanetra kelas V SDLB Negeri Kedungkandang Malang. Data rekapitulasi rata-rata pre-test dan post-test adalah sebagai berikut :

Berikut ini datar hasi rekapitulasi nilai pre-test dan post-test yang disajikan pada diagram. Adapun diagram batang hasil nilai pre-test dan post-test kemampuan mengenal geometri bangun datar siswa tunanetra kelas 5 SDLB Negeri Kedungkandang Malang sebelum dan sesudah menggunakan metode Teori Van Hiele dapat di lihat pada tabel 3. Berdasarkan diagram batang dapat diketahui bahwa nilai rata-rata pada pretest yang diperoleh siswa lebih rendah dibandingkan dengan nilai rata-rata pada postest. Perbedaan nilai yang diperoleh pada pretest dan postest ini menunjukkan adanya perbedaan pemahaman geometri siswa tunanetra sebelum dan sesudah diberi perlakuan (treatment) yaitu pembelajaran berbasis Van Hiele.

Pembelajaran dimulai dengan salam, presensi, dan apersepsi. Kemudian untuk membuka materi pembelajaran, guru memberikan pertanyaan mengenai apa yang siswa ketahui tentang bangun datar berdasarkan bentuknya, Pada pembelajaran perlakuan pertama siswa diminta untuk mengamati replica bangunan Kemudian siswa diberi pertanyaan bagaimana bentuk yang ada pada replika bangunan berdasarkan rabaan mereka, Setelah siswa mampu membedakan beberapa bentuk pada replika bangunan siswa menuliskan apa yang mereka raba berdasarkan bentuknya, seperti : terdapat kotak di bagian badan replika, bundar di bagian atas replika. 


\section{Gambar 1 diagram hasil Pretest dan postest}

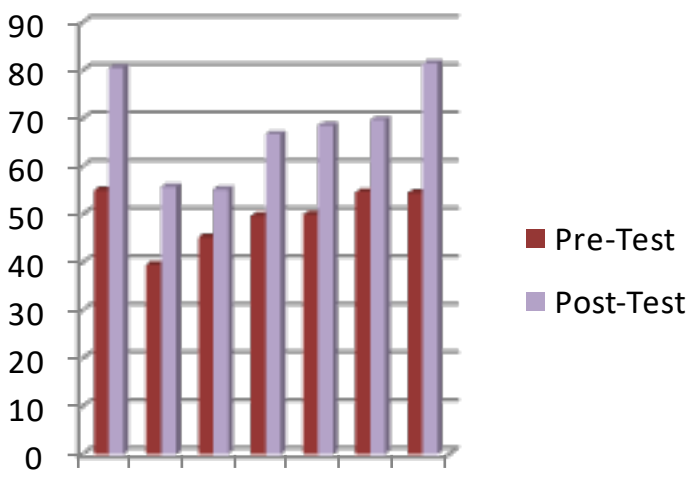

Ds Ob Ah Pu Se Rz Az

Setelah itu siswa diberikan beberapa bentuk bangun terdapat 4 bangun di hadapan mereka kemudian siswa diberikan pertanyaan mengenai bangun yang termasuk segi banyak dan bukan segi banyak. Dari materi ini siswa bisa menganalisis dengan mudah berdasarkan bentuknya. Kemudian siswa mengerjakan lembar kerja siswa mengenai membedakan beberapa bentuk bangun segi banyak dan bukan segi banyak.

Berdasarkan diagram diatas dapat diketahui bahwa nilai rata-rata pada pretest yang diperoleh siswa lebih rendah dibandingkan dengan nilai ratarata pada postest. Perbedaan nilai yang diperoleh pada pretest dan postest ini menunjukkan adanya perbedaan pemahaman geometri siswa tunanetra sebelum dan sesudah diberi perlakuan (treatment) yaitu pembelajaran berbasis Van Hiele.

Pembelajaran dimulai dengan salam, presensi, dan apersepsi. Kemudian untuk membuka materi pembelajaran, guru memberikan pertanyaan mengenai apa yang siswa ketahui tentang bangun datar berdasarkan bentuknya, Pada pembelajaran perlakuan pertama siswa diminta untuk mengamati replica bangunan Kemudian siswa diberi pertanyaan bagaimana bentuk yang ada pada replika bangunan berdasarkan rabaan mereka, Setelah siswa mampu membedakan beberapa bentuk pada replika bangunan siswa menuliskan apa yang mereka raba berdasarkan bentuknya, seperti : terdapat kotak di bagian badan replika, bundar di bagian atas replika. Setelah itu siswa diberikan beberapa bentuk bangun terdapat 4 bangun di hadapan mereka kemudian siswa diberikan pertanyaan mengenai bangun yang termasuk segi banyak dan bukan segi banyak. Dari materi ini siswa bisa menganalisis dengan mudah berdasarkan bentuknya. Kemudian siswa mengerjakan lembar kerja siswa mengenai membedakan beberapa bentuk bangun segi banyak dan bukan segi banyak.

Pada perlakuan kedua dan ketiga siswa diberikan materi mengenai pengenalan nama-nama bangun

geometri terutama bangun datar beserta sifatnya yang di bantu dengan alat peraga bangun datar. Siswa meraba beberapa bangun datar seperti persegi, persegi panjang, dan jajargenjang kemudian mengenali berdasarkan bentuknya, dengan mendengarkan penjelasan dari guru. Kemudian siswa mengamati replica bangunan, kemudian siswa menyebutkan bangun datar apa saja yang ada pada permukaan replica bangunan tersebut. Selesai mengenali siswa mengerjakan lembar kerja untuk menuliskan 2 bangun beserta sifat-sifatnya, dan membedakan bangun segi banyak yang ada pada replica bangunan.

Pada pembelajaran keempat pada pembelajaran ini siswa diajak untuk mengenali lingkungan disekitar terutama dikelas untuk mengenali beberapa bentuk benda yang ada didalam kelas. Siswa diminta untuk mengenali 3 benda yang memiliki bentuk berbeda atau sama kemudian menyebutkan benda / permukaan benda tersebut salah satu contoh dari bangun datar apa, kemudian siswa menjelaskan alasannya mengapa dia bisa menyebutkan benda tersebut seperti salah salah satu contoh bangun datar. Contoh, benda: meja alasan: memiliki 4 sisi yang sama yaitu dua sisi panjang dan 2 sisi pendek. Setelah itu siswa menuliskan benda apa saja yang mereka temui didalam kelas dan menyebutkan termasuk dalam bangun datar apa. Setelah materi selesai siswa diberikan evaluasi untuk mengetahui kompetensi yang dicapai siswa hari itu dan pada pertemuan sebelumnya.

\section{Pembahasan}

Pelaksanaan pembelajaran pada penelitian ini dilakukan pada tunanetra kelas $\mathrm{V}$ SDLB Kedungkandang Malang dengan jumlah 7 siswa . Kondisi kemampuan awal yang dimiliki siswa sebelum diberikan treatment, sangat rendah. Siswa tampak masih kebingungan, terlihat saat peneliti memberikan pertanyaan mengenai bangun segi banyak dan bukan segi banyak, selain itu juga pada pertanyaan perbedaan persegi panjang dan trapesium siswa hanya memberikan satu penjelasan saja yaitu sama-sama memiliki 4 sisi. Selain itu beberapa siswa sering bertanya mengenai soal yang diberikan peneliti dan meminta pengulangan pembacaan soal karena terdapat siswa yang mengalami kesulitan dalam membaca sehingga perlu dibantu Solichah (2014:5). Hal ini juga ditunjukan pada saat siswa setelah mengerjakan soal pre-test, banyak jawaban siswa yang masih salah dan beberapa jawaban yang kosong. Kesulitan mempelajari matematika bagi sebagian siswa dikarenakan beberapa alasan yang belum dipahami betul oleh siswa diantaranya adalah kekeliruan cara pengerjaan, dan pemahaman mengenai konsep yang terdapat di matematika, sehingga mempengaruhi pencapaian pelajaran matematika (Ludfi dalam ICSAR, 2017:337).

Berdasarkan hasil pretest yang diperoleh siswa diketahui bahwa pemahaman geometri siswa tunanetra 
kelas V SDLB Negeri Kedungkandang Malang sebelum melakukan pembelajaran berbasis Van Hiele yaitu sebanyak 14\% siswa gagal dan 86\% siswa kurang.

Geometri adalah studi tentang bidang datar dan bangun datar dan berbagai bentuk ruang. Jadi geometri adalah bagian dari matematika yang merupakan pengetahuan tentang hubungan dan pemahaman secara mendalam tentang bangun datar dan bidang datar serta sifat-sifatnya yang berguna dalam berbagai situasi dan berkaitan dengan topic matematika dan pelajaran lainnya (Aviana, 2012).

Anak-anak yang memiliki hambatan dalam penglihatan memiliki kebutuhan yang harus dialaminya sendiri secara konkret dan melakukan apa yang dia pelajarai untuk membantunya membuat persepsi sendiri (learning by doing). Mereka dapat melakukan kedua hal diatas dengan mengorientasikan pengalaman belajar dengan mengalami kejadian nyata dan menggunakan benda atau material yang khsusus seperti menyediakan bermacam-macam pengalaman mengenal bentuk, ukuran, dan tekstur (Hildayani, 2014). Menurut Walle (2006:150) bahwa pengalaman akan bentuk dan ruang, ketika dilatih secara konsisten, sungguh akan mengembangkan pemahaman akan hubungan bentuk dan ruang.

Kondisi siswa tunanetra dalam memahami geometri setelah diberikan perlakuan (treatment) sebanyak 4 kali hasil belajar yang diperoleh meningkat dibandingkan dengan kondisi awal sebelum diberikan perlakuan (treatment) atau dapat dikatakan siswa sudah mampu memahami geometri sehingga nilai siswa mengalami peningkatan. Saat mengerjakan soal pada pembelajaran posttest siswamenjadi kondusif. Beberapa siswa terlihat tenang saat mengerjakan soal, namun beberapa siswa juga ada yang masih terlihat bingung karena saat ditanya jawaban mereka masih banyak yang rancau dengan soal yang ditanyakan sehingga masih perlu di bantu oleh guru. Selain itu pada lembar jawaban siswa tampak sudah terisi penuh tidak seperti sebelumnya.

Berdasarkan hasil posttest yang dilakukan siswa diketahui bahwa pemahaman geometri bangun datar siswa tunanetra kelas V SDLB Negeri Kedungkandang Malang mengalami peningkatan. Hal ini dapat dibuktikan dari data yang diperoleh siswa yaitu siswa yang memiliki kriteria pada tabel distribusi cukup sebanyak 29\% dan siswa yang memiliki kriteria pada tabel baik sebanyak $42 \%$, dan siswa yang memiliki criteria pada tabel sangat baik sebanyak 29\%.

Adanya hambatan yang dimiliki oleh siswa tunanetra menyebabkan mereka memanfaatkan indera pendengaran dan perabaan saja dalam menerima informasi. Dalam pelaksanaan pembelajaran perlu adanya kesesuaian dengan karakteristik dan kemampuan siswa. Menurut Wardani (2009) pendengaran memegang peranan penting dalam kegiatan belajar di sekolah dibanding penglihatan.
Selain itu peningkatan dalam penggunaan media pembelajaran yang bersifat auditory dan taktil dapat mengurangi hambatan dalam kegiatan akademik siswa tunanetra. Siswa tunanetra memeiliki daya ingat serta intelegensi yang baik dimana mereka memanfaatkan indera yang ada seperti kemampuan taktik yang bisa merasakan ujung-ujung jarinya sebagai indera penglihatan. . (Aviana, 2012). Untuk memaksimalkan kemampuan yang ada pada diri mereka saat belajar geometri dan untuk mendeskripsikan suatu benda siswa dapat menggunakan indera raba dengan jarijarinya, sehingga siswa mampu menangkap konsep yang diberikan oleh guru dan akan tertanam dipikiran siswa.

Menurut Nur'aeni (2010) untuk mempercepat meningkatnya berpikir siswa sekolah dasar khususnya pada topic pembelajaran geometri dapat ditingkatkan melalui pembelajaran dengan tahap Van Hiele dan dengan kegiatan yang membuat siswa aktif mengenal objek yang sudah mereka telaah.

Pembelajaran dengan berbasis teori Van Hiele memiliki 5 tingkatan, namun yang digunakan peneliti hanya 3 tingkatan yaitu: (Walle, 2006:151). Dalam teori Van Hiele mengemukakan 5 (lima) tahapan siswa dalam belajar geometri, yaitu (a) tahapan pengenalan, (b) tahap analisis, (c) tahap pengurutan (d) tahap deduksi, (f) tahap akurasi atau keakuratan.

Pembelajaran dengan menggunakan teori Van Hiele dapat dipahami siswa dengan baik, siswa dapat mempelajari matematika berdasarkan urutan tingkatan kesukaran yang dimulai dari tingkatan yang paling mudah sampai tingkatan yang sulit sesuai dengan tujuan yang diinginkan. Kelebihan dari pembelajaran berbasis Van Hiele adalah kemapuan pemahaman siswa lebih baik, selain itu bersifat intrinsik dan ekstrisik, yang artinya objek yang masih kurang jelas akan menjadi objek yang jelas pada tahap berikutnya (Wahyuni, 2012:16).

\section{KESIMPULAN DAN SARAN}

\section{Kesimpulan}

Berdasarkan hasil penelitian yang telah dikakukan, dan pada hasil analisis serta pembahasan pada bab sebelumnya dapat diambil kesimpulan sebagai berikut: (1) Kemampuan memahami geometri bangun datar siswa tunanetra sebelum menggunakan metode teori Van Hiele diperoleh rata-rata 49,8 yang termasuk dalam kategori kurang mampu. (2) Kemampuan memahami geometri bangun datar siswa tunanetra sesudah menggunakan metode teori Van Hiele diperoleh rata-rata 68,1 yang termasuk dalam kategori baik. (3) Kemampuan memahami geometri bangun datar siswa tunanetra setelah memanfaatkan metode teori Van Hiele mengalami peningkatan. Terbukti berdasarkan rata-rata post-test( 68 )yang 
lebih besar dari rata-rata pre-test $(49,8)$. Ditunjukkan dengan hasil perolehan nilai siswa $\mathrm{Ob}$, Ah berada pada rentang nilai 56-65 yang termasuk dalam kategori nilai cukup, siswa $\mathrm{Sk}, \mathrm{Pu}, \mathrm{Rz}$ berada pada rentang nilai 6679 yang termasuk dalam kategori nilai baik, dan siswa Ds Az berada pada rentang nilai 80-100 yang termasuk dalam kategori nilai sangat baik.

\section{Saran}

Berdasarkan penelitian mengenai pembelajaran berbasis teori Van Hiele terhadap pemahaman geometri bangun datar siswa tunanetra kelas V SDLB Negeri Kedungkandang Malang, dapat dikemukakan saransaran sebagai berikut : (1) Untuk guru pembelajaran dengan metode Van Hiele dapat dijadikan alternative dalam penyampaian pembelajaran karena terdapat tahapan-tahapn pembelajaran dan tahapan berpikir siswa sehingga dapat menyesuiakan kemampuan siswa. (2) Untuk penelitian selanjutnya, penelitian ini hanya berfokus pada pembelajaran matematika geometri bangun datar. Untuk peneliti selanjutnya sebaiknya dilakukan pada pembelajaran bangun ruang.

\section{DAFTAR RUJUKAN}

Arikunto, S. (2012). Prosedur Penelitian Suatu Pendekatan Praktik. Jakarta: Rineka Cipta

Aviana W. P. (2012. Pembelajaran Geometri pada Siswa Tunanetra di SLB-A Dria Adi Semarang (Doctoral dissertation, Program Studi Pendidikan Matematika FKIP-UKSW).

Efendi, M. (2006). Pengantar Psikologi Anak Berkelainan. Jakarta:PT BumiAksara.

Hildayani,. (2014). Penanganan Anak Berkelainan (Anak Dengan Berkebutuhan Khusus). Jakarta:Universitas Terbuka.
Hudojo, H. (2005). Pengembangan Kurikulum dan Pembelajaran Matematika. Malang: IKIP Malang UM Press.

Ludfi, M.K. , Sudrajat D A, Perdana H.E.(tanpa tahun) Ketrampilan Matematika Pada Peserta Sekolah Dasar. Journlal of International Conference On Special Education In Shouteast Asia Region $7^{\text {th }}$ Series.

Nur'aeni, H. E. (2010). Pengembangan Kemampuan Komunikasi Geometris Siswa Sekolah Dasar Melalui Pembelajaran Berbasis Teori Van Hiele.

Nuraini, S. 2010. Penerapan Pembelajaran Geometri Berbasis Teori Van Hiele (PBH) Pokok Bahasan Sifat-Sifat Segiempat Siswa Kelas VIIB SMP Negeri 5 Tanggul. (Skripsi, Program Studi Pendidikan Matematika. FKIP-Universitas Jember.)

Smart, A. (2010). Anak Cacat Bukan Kiamat: Metode Pembelajaran Dan Terapi Untuk Anak Berkebutuhan Khusus. Yogyakarta:Katahati

Solichah, I. (2014). Alat peraga untuk pelajar tunarungu: Penggunaan bentuk dua dimensi bangun datar pada siswa tunarungu. Media Guru.

Sugiyono. (2015). Metode Penelitian Pendidikan Pendekatan Kuantitatif, Kualitatif dan R\&D. Alfabeta: Bandung.

Wahyuni, R. A. (2012). Efektifitas Penerapan Model Pembelajaran Van Hiele Terhadap Hasil Belajar Matematika Bagi Siswa Kelas V SD Negeri Bringin Kecamatan Bringin Kabupaten Semarang Semester II Tahun Pelajaran 2011/2012. FKIP Universitas Kristen Satya Wacana Salatiga.

Wardani, I.,. (2009). Pengantar Pendidikan Luar Biasa. Jakarta:Universitas Terbuka.

Walle, J.A.V.D. (2006). Elementry and Middle School Matemathics. Dalam Suyono (Ed). Pengembangan Pengajaran Sekolah Dasar dan Menengah Matematika.Erlangga. 